Flewett, T. H. \& Challice, C. E. (1951). J. gen. Microbiol. 5, 279-286.

\title{
The Intracellular Growth of Fowl-Plague Virus
}

\section{A Phase-Contrast and Electron Microscopical Study of Infected Tissue Cultures}

\author{
By T. H. FLEWETT and C. E. CHALliCE \\ National Institute for Medical Research, Mill Hill, London N.W. 7
}

\begin{abstract}
SUMMARY: The changes in fowl-plague infected tissue cultures have been investigated by the phase-contrast and electron microscopes. The nucleolus of infected cells first increased in size and then became granular and highly refractile, finally disintegrating into fragments about $64 \mathrm{hr}$. after infection. After $36-48 \mathrm{hr}$., when the inclusions were already developed, filaments were found, usually in bundles, possibly having escaped from the nucleus into the cytoplasm; a few filaments showed segmentation into spherical bodies and shorter filaments. A possible life cycle is suggested for the virus : first, penetration of the nucleus and growth within it, then extension into the cytoplasm in a filamentous form, and eventual segmentation of some of the filaments into elementary bodies.
\end{abstract}

It was shown by Porter, Claude \& Fullam (1945) that satisfactory electron micrographs could be obtained of the cytoplasm of well-extended chick fibroblasts. Subsequently it was demonstrated that intracellular virus particles, as small as $60 \mathrm{~m} \mu$. in size, could readily be resolved (Claude, Porter \& Pickels, 1947; Bang \& Gey, 1948, 1949; Porter \& Thompson, 1947, 1948). The use of the phase-contrast microscope in the study of viral inclusion bodies was demonstrated by Angulo, Richards \& Roque (1949) and Angulo (1949) for a variety of viral infections.

When Chu, Dawson \& Elford (1949) demonstrated such long and numerous filamentous forms in recently isolated strains of A-prime influenza, it seemed that the direct examination of infected tissue-culture cells might give some information as to whether these filamentous forms represented a stage in the life cycle of the virus.

The morphology of fowl-plague virus is very similar to that of influenza $\mathbf{A}$ in that filaments and elementary bodies of the same size (Dawson \& Elford, 1949) occur in infected allantoic fluid. The virus is highly pathogenic for chick embryo tissues; infection can easily be recognized by the presence of intranuclear inclusion bodies; and the virus is pantropic for chick cells of all kinds (Findlay, Mackenzie \& Stern, 1937). It is therefore suitable for an investigation of this type.

\section{MATERIALS AND METHODS}

One of the strains of fowl-plague virus used was obtained from Dr F. Doyle, and is the strain used by Dawson \& Elford (1949); the other we isolated from the dried liver tissue of a fowl from an epizootic in France, kindly sent by Dr Lépine. Nearly all the observations were made with the first strain; the second took slightly longer to kill chick embryos, but in all other respects appeared to behave similarly. The tissues were pieces of amnion and pectoral 
muscle from 10-day-old eggs and the nutrient medium was amniotic fluid from normal 10-day eggs.

The fluid used to infect the tissue culture was prepared by inoculating 10-day eggs by the amniotic route with a 1/1000 dilution of allantoic fluid containing fowl-plague virus with a haemagglutination titre of 2500 to 10,000 . The eggs were incubated for $18 \mathrm{hr}$. at $37^{\circ}$. After chilling overnight at $4^{\circ}$, the amniotic fluid was harvested; 1 part of Hartley's broth containing $10 \%$ normal horse serum was added to 4 parts of the infected amniotic fluid, and the mixture was then filtered through a 'Gradocol' membrane of average pore diameter 0.65$0.7 \mu$., in order to remove the greater part of the filamentous forms of the virus. Preparations of virus before and after filtration were made on haemolysed chick erythrocytes by the method of Dawson \& Elford (1949) and photographed in the electron microscope; they showed that only short filaments up to $1 \mu$. in length and spherical particles were present in the filtrate. The haemagglutination titres of the filtrates were determined, using $0.5 \%$ of chick erythrocytes, with a final volume of $0.5 \mathrm{ml}$. in each dilution. The sedimentation patterns were read after $1 \mathrm{hr}$. at room temperature, and the titres varied between $1 / 20$ and $1 / 80$ in different preparations. The filtrates were stored in $0.5 \mathrm{ml}$. amounts at $-76^{\circ}$ until required.

At first we tried the methods of Porter et al. (1945) for preparing cultures for the electron microscope; but great difficulty was encountered in detaching the 'Formvar' membrane from the cover-slip. The following method was found to give consistent and satisfactory results:

A Petri dish was filled with Simms's solution, adjusted to a $\mathrm{pH}$ about $\mathbf{7 \cdot 4}$. A drop of a $1 \%$ solution of 'Formvar' (polyvinyl formal) in ethylene dichloride was allowed to fall on to its surface; the drop spread and the solvent evaporated to leave a thin membrane. The solution of 'Formvar' appears to be selfsterilizing. This membrane was then picked up on a cover-slip so that it overlapped the cover-slip all round. Three or four small fragments of tissue (about $\frac{1}{2} \mathrm{~mm}$. square) were placed on the membrane in a small drop of amniotic fluid. The cover-slip was inverted over a hollowed slide, sealed with paraffin and incubated for 2 days as a 'lying-drop' (Fig. 1). It was then examined to be sure that outgrowth had occurred. The cover-slip, with the attached membrane, was removed with a hot scalpel, and a drop of infected amniotic fluid was added to the culture. The cover-slip was then sealed to the hollowed slide again, and the preparation returned to the incubator. The cultures were examined at intervals by the phase-contrast microscope, and specially thin areas were selected for mounting for the electron microscope.

For mounting, the culture was opened as before, and Simms's solution was run under the edge of the membrane until it was raised from the surface of the cover-slip. The culture was washed carefully with Simms's solution to remove as much free protein as possible, and then a drop of a $2 \%(\mathrm{w} / \mathrm{v})$ solution of osmium tetroxide in water was added, and left to fix for $2 \mathrm{hr}$. The fixation was complete quite quickly, but the prolonged action of the osmium tetroxide increased contrast slightly.

A horseshoe-shaped piece of glass rod $5 \mathrm{~mm}$. in diameter was placed on the 
membrane to hold it in position, so that the culture lay between the ends of the horseshoe. The culture was washed in several changes of double-distilled water, and the membrane was floated upwards so that it was about $2 \mathrm{~mm}$. above the cover-slip (Fig. 2). An electron microscope grid of 200-mesh was pushed into position between the membrane and the cover-slip with a glass rod so that the cells to be examined lay over the central squares of the grid. The distilled water was then aspirated from beneath the grid so that the membrane gradually sank on to it. The position of the cells with respect to the grid was controlled under the microscope during the mounting; only the central nine squares of the grid were available for examination. The preparation was allowed to dry and was examined in the microscope. The techniques of mounting tissue cultures for the electron microscope will be more fully described elsewhere.

Most of the electron micrographs were taken with the Siemens microscope at a magnification of about 5000 , at $75 \mathrm{kV}$. and using a $70 \mu$. objective aperture. It was found, however, that better definition of thicker parts of the cell near the nucleus was obtained at $100 \mathrm{kV}$. using a $20 \mu$. objective aperture. Some photographs were taken with the R.C.A. type E.M.B. microscope at $60 \mathrm{kV}$. with no objective aperture, at a magnification of 11,000.

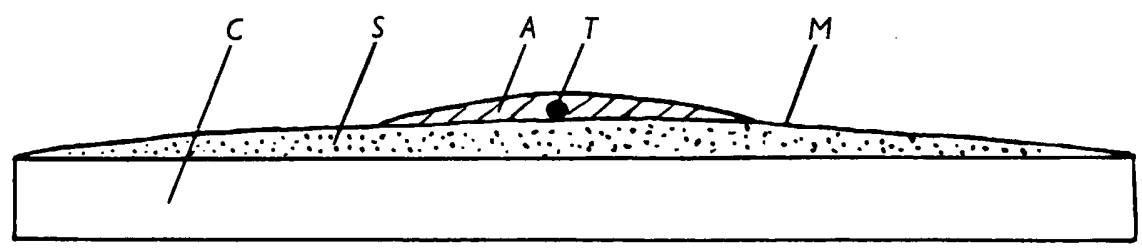

Fig. 1. $A$, amniotic fluid; $C$, coverslip; $M$, membrane; $S$, Simms's solution; $T$, tissue explant.

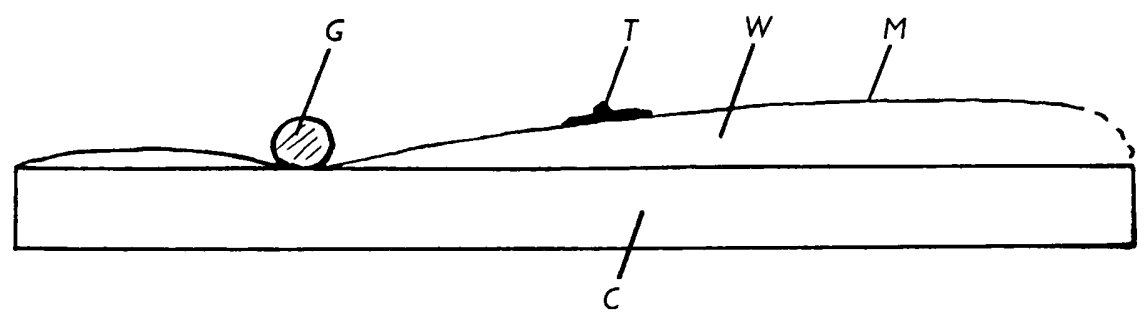

Fig. 2. $C$, cover-slip; $G$, glass horseshoe; $M$, membrane; $T$, tissue explant; $W$, distilled water.

\section{RESULTS}

When amnion was cultured, the growth was mainly epithelial; fibroblasts were supplied from fragments of lung or pectoral muscle. Some growth continued after the addition of virus, and mitoses could be seen even $48 \mathrm{hr}$. after inoculation.

W ith the phase-contrast microscope the first change visible after infection was an increase in the size of some of the nucleoli, both in epithelium and in fibroblasts (Pl. 1, fig. 2; compare with normal in fig. 1). This change was first 
visible in fibroblasts about $24 \mathrm{hr}$. after infection (Pl. 1, fig. 3), and in epithelium $36 \mathrm{hr}$. after infection (Pl. 1, fig. 4). After $48 \mathrm{hr}$. the change was more marked, and in addition, many of the affected nucleoli became much more refractile (Pl. 1, fig. 5) and instead of the smooth homogeneous appearance of the normal nucleolus, they acquired a distinctive structure almost micro-crystalline in appearance. In many nuclei, highly refractile fragments, presumably derived from the altered nucleolus, were seen in the nucleoplasm (Pl. 1, fig. 6). Some of the altered nucleoli grew to occupy more than half of the nucleus; they probably constitute the intranuclear inclusions described by Findlay et al. (1937) and other authors. The nuclear membrane then became invisible. Occasionally the whole inclusion broke up (Pl. 1, fig. 7).

After $48 \mathrm{hr}$. incubation, the outgrowth already looked 'moth-eaten', where cells had fallen out, and amorphous cellular debris could be seen floating in the culture medium. About $64 \mathrm{hr}$. after inoculation, many more of the cells showed intranuclear inclusions and the disintegration of the outgrowth was much more advanced; after $72 \mathrm{hr}$. little was left of the outgrowth and the supernatant fluid was thick with debris.

Although nuclear changes might be advanced, the mitochondria showed little change. They appeared, 24 $\mathrm{hr}$. after inoculation, perhaps larger than normal; after $48 \mathrm{hr}$., some were somewhat shorter and thicker, with clubbed ends. Only when the cell was about to disintegrate did the mitochondria become rounded up.

Small granular inclusions were sometimes seen in the cytoplasm near the nucleus; but they occurred in only a few of the cells; and as similar structures were very occasionally seen in uninfected preparations, their nature is uncertain.

As the infection progressed, many of the infected cells, especially epithelium, became vacuolated. The vacuoles were concentrated around the nucleus; small particles in rapid Brownian motion could be seen within them. These vacuoles were not as refractile as the fat occurring in cells grown in a medium of high protein content; a few small highly refractile fat droplets were usually seen, but did not increase in number with infection.

Cultures were mounted for the electron microscope $6,12,18,24,36,48,64$ and $72 \mathrm{hr}$. after inoculation with virus. No virus particles could be seen at all until after $36 \mathrm{hr}$, when filaments of virus were found in the cytoplasm of fibroblasts, occurring in bundles of a few filaments, up to $2 \mu$. in length. These filaments, in some cases at any rate, appear to come from the nucleus; Pl. 2, fig. 8, shows a bunch of filaments apparently emerging from the nucleus of an epithelial cell. No elementary bodies could be seen at this stage.

After $48 \mathrm{hr}$., in most preparations, long bundles of filaments up to $7 \mu$. in length, with many separate individual filaments, each about $0 \cdot 1 \mu$. thick, could be found (Pl. 2, figs. 9, 10; Pl. 3, figs. 11, 12). Some of them could be seen apparently undergoing segmentation into spherical bodies and into shorter filaments. The bundles of filaments were mostly situated near the nucleus, but a few were found in the processes of fibroblasts. No branching filaments were discovered. There were no colonies of spherical elementary bodies and only 
a few isolated elementary bodies were found, and then only in association with the long forms.

In the cytoplasm of fibroblasts peculiar spherical structures, about $3 \mu$. in diameter, with areas of greater density within them, were occasionally found (Pl. 3, fig. 12). No definite virus particles could be made out within these structures, and they were never found in control material. Their significance is unknown. Virus filaments bent in an acute angle showed a swelling at the 'elbow' (Pl. 2, fig. 10).

Finally, as the cell disintegrated, the regular outline of the cytoplasm was lost, and amorphous debris was seen with large numbers of filaments lying in and around it; many of these showed segmentation into shorter elements and occasionally into spherical bodies of the same thickness; and a few isolated spherical elementary bodies were found (Pl. 3, fig. 13). One fibroblast, $64 \mathrm{hr}$. after inoculation, showed an area of greater density at the edge of the cytoplasm with many long filaments radiating from it, suggesting in appearance a colony of virus particles in the act of rupture (Pl. 3, fig. 11).

The nucleus was always so thick as to make it almost opaque to electrons. The nucleolus could usually be made out, but the detail which was resolved was no more, and indeed usually less than could be seen by the phase-contrast microscope.

When fixation with osmic acid was limited to 30 sec., with a $20 \mu$. objective aperture and an accelerated potential of $100 \mathrm{kV}$. much more detail could sometimes be made out in the nucleus; but the electron scattering was so great that virus particles could not have been made out in it.

By hydrolysis for $7 \mathrm{~min}$. at $56^{\circ}$ in $\mathrm{N}-\mathrm{HCl}$, the area around the nucleus could be made more transparent to electrons; Pl. 2, fig. 10 and Pl. 3, fig. 12, are of preparations so treated. Fowl-plague and influenza viruses adsorbed upon chick red cells showed no apparent change after this treatment when examined in the electron microscope.

We have always found the cytoplasm in both epithelium and fibroblasts to show only finely reticular structure; the coarse fibrils described by Bang \& Gey (1948) in rat fibroblasts were not seen. Excessive washing with Simms's solution may, however, induce the appearance of coarse reticulation; and no washing at all may result in the precipitation of threads, presumably fibrin, which may simulate virus filaments. These fibrin threads may be recognized by their tapered ends, their irregular thickness-usually $50 \mathrm{~m} \mu$. or less-and their relatively low contrast compared with virus particles.

Many attempts were made to demonstrate influenza virus within infected cells by the method described above. A few electron micrographs were obtained showing filamentous structures within cells, Pl. 3, fig. 14, but we have not been able to repeat these results.

\section{DISCUSSION}

The question arises as to whether the filaments and elementary bodies occurring within infected cells are, in fact, fowl-plague virus particles. The evidence that they are is: 
(1) The particles and filaments are the same diameter as fowl-plague virus.

(2) They are only found in infected cells and never in control preparations.

(3) Their appearance is associated with the presence of inclusion bodies in the cultured cells and the subsequent destruction of the outgrowth.

(4) Multiplication of virus in the tissue cultures can be demonstrated by other means.

Filamentous structures which might simulate virus are collagen and fibrin strands. Collagen, like the filaments described here, occurs in bundles (Heinmets \& Golub, 1948) and some of the collagen fibrils they illustrated are of about the same thickness as ours. But we have never seen the characteristic regular spacing of the transverse bands of collagen at $65 \mathrm{~m} \mu$. as described by them; and furthermore, long filaments appear in infected epithelial cells growing in sheets in which there were no fibroblasts; epithelium does not produce collagen. Mitochondria are readily distinguished by their much greater size and less distinct outline.

The uniform thickness, the segmentation, the peculiar angulation, the relatively high electron-density and the strictly intracellular position in the earlier stages of growth all suggest that they are not fibrin. The similar filaments occurring in infected allantoic fluid resist digestion with crude pancreatic extract containing trypsin and lipase.

It seems likely then, that these structures do in fact represent the virus itself; and if so, they must have developed within the cell from the elementary bodies and the very short rods present in the original inoculum. What happens in the early stages of intracellular growth of virus is unknown; no virus is found in the cytoplasm until the intranuclear inclusions are well developed; and when it is found, it is in the form of long filaments already arranged in bundles, and there is no direct evidence of the growth of these from the elementary bodies of the inoculum. A tentative hypothesis might be put forward that fowl-plague virus penetrating a cell first invades the nucleus, multiplying in or in the region of the nucleoli, and that only after a certain stage has been reached does it extend into the cytoplasm in a filamentous form.

The segmentation of the filaments is associated with the disintegration of the infected cell, and it seems possible that segmentation might be due to the action of enzymes released at this stage. Mixed enzymes from bovine pancreas have no demonstrable effect, and unless there are special enzyme systems in the infected cell induced or modified by the infection, it must be assumed that the segmentation is spontaneous.

The association of filamentous forms with the elementary bodies has recently been described independently in the case of bacteriophage by Herčik (1950) and Wyckoff (1950); it was there suggested that the filaments might be aberrant forms of virus developing in an unsuitable environment. That is not likely to be the case with fowl-plague developing in the embryonic tissue of the natural host; it would, however, be interesting to examine the pericardial fluid from an adult bird dying of fowl-plague. If one elementary body should grow into one 
filament, no increase in infectivity would be expected, while there might be a considerable increase in amount of antigen as determined by complement fixation until segmentation into elementary bodies took place.

\section{ADDENDUM}

Murphy, Karzon \& Bang (1950) have just published a paper illustrating filamentous forms of PR 8 influenza virus in disintegrating cells of infected tissue cultures. They consider, as we do, that the filamentous forms probably undergo segmentation into elementary bodies.

We would like to thank Dr I. M. Dawson, with whose collaboration one of us (T. H. F.) devised the technique described; Drs C. H. Andrewes and W. J. Elford for their advice and encouragement; $\mathrm{Mr} \mathrm{J}$. Smiles for some of the phase-contrast photographs; and Dr Lépine for a strain of fowl-plague virus.

\section{REFERENCES}

Angulo, J. J., Richards, O. W. \& Roque, A. L. (1949). Demonstration of viral inclusion bodies in unstained tissue sections with the aid of the phase microscope. 1. The inclusion bodies of yellow fever, herpes simplex, fowl pox and distemper. J. Bact. 57, 297.

Angulo, J. J. (1949). Demonstration of viral inclusion bodies in unstained tissue sections with the aid of the phase microscope. Arch. ges. Virusforsch. 4, 118.

BANG, F. B. \& GEY, G. O. (1948). A fibrillar structure in rat fibroblasts as seen by electron microscopy. Proc. Soc. exp. Biol., N.Y., 69, 86.

BANG, F. B. \& GEY, G. O. (1949). Electron microscopy of tissue cultures infected with the virus of Eastern Equine Encephalomyelitis. Proc. Soc. exp. Biol., N.Y., $71,78$.

Chu, C. M., Dawson, I. M. \& Elford, W. J. (1949). Filamentous forms associated with newly isolated influenza virus. Lancet, $\mathrm{i}, 602$.

Claude, A., Porter, K. R. \& Pickels, E. G. (1947). Electron microscope study of chicken tumour cells. Cancer Res. 7, 421.

Dawson, I. M. \& Elford, W. J. (1949). The investigation of influenza and related viruses in the electron microscope, by a new technique. J. gen. Microbiol. 3, 298.

Findlay, G. M., Mackenzie, R. D. \& Stern, R. O. (1937). The histopathology of fowl pest. J. Path. Bact. 45, 589.

Heinmets, F. \& Golub, O. J. (1948). Observations on the growth of psittacosis virus in chorioallantoic membranes by electron microscope. J. Bact. 56, 509.

Herčık, F. (1950). Some observations about the morphology of bacteriophage. Experentia, 6, 64.

Murphy, J. S., Karzon, D. T. \& Bang, F. B. (1950). Studies of influenza A (PR 8) infected tissue cultures by electron microscopy. Proc. Soc. exp. Biol., N.Y., 73, 596.

Porter, K. R., Claude, A. \& Fullam, E. F. (1945). A study of tissue culture cells by electron microscopy. (Methods and preliminary observations.) J. exp. Med. 81, 233.

Porter, K. R. \& Thompson, H. P. (1947). Some morphological features of cultured rat sarcoma cells as revealed by the electron microscope. Cancer. Res. 7, 431.

Porter, K. R. \& Thompson, H. P. (1948). A particulate body associated with epithelial cells cultured from mammary carcinomas of mice of a milk factor strain. J. exp. Med. 88, 15.

WyскоғF, R. W. G. (1950). Filaments in cultures of bacteriophage. Experientia, 6, 66. 


\section{DESCRIPTION OF PLATES}

Plate 1. All $\times 1500$

Fig. 1. Nucleus and mitochondria of a normal epithelial cell. The nucleoli are small and not very refractile. The nuclear membrane is clearly defined. The mitochondria are shorter than usual.

Fig. 2. Nucleus and filamentous mitochondria of epithelial cell $24 \mathrm{hr}$. after inoculation with fowl-plague virus. The nucleus is greatly enlarged.

Fig. 3. Nucleus of fibroblast $24 \mathrm{hr}$. after inoculation. The nucleolus is enlarged and more refractile than normal; the mitochondria have become rounded up.

Fig. 4. Nucleus of epithelial cell $36 \mathrm{hr}$. after inoculation. The nucleolus is highly refractile, as indicated by the halo, although not much larger than normal.

Fig. 5. Swollen granular intranuclear inclusions; epithelium $48 \mathrm{hr}$. after inoculation. The mitochondria have almost disappeared.

Fig. 6. Nuclei of epithelial cells $48 \mathrm{hr}$. after inoculation. The inclusions are beginning to break up into the small granules into the nuclei. The cytoplasm is vacuolated and the mitochondria poorly defined.

Fig. 7. Fibroblast, $48 \mathrm{hr}$. after inoculation. The inclusion has disintegrated into fragments. The mitochondria have disappeared. The arrow indicates the nucleus.

\section{Plate 2}

Fig. 8. Filaments escaping from nucleus of an epithelial cell $48 \mathrm{hr}$. after inoculation. (The nucleus is the dense area at the top.) The filaments appear broader in the vacuole than in the thickness of the cytoplasm. The arrow indicates a mitochondrion. $100 \mathrm{kV}, 20 \mu$. objective aperture. $\times 10,000$.

Fig. 9. Bundles of filaments in the cytoplasm of an epithelial cell, $48 \mathrm{hr}$. after inoculation. One filament is segmented into spherical particles. The cytoplasm at the top has been torn in drying. $75 \mathrm{kV} ., 70 \mu$. objective aperture. $\times 10,000$.

Fig. 10. Filaments in fibroblast, $48 \mathrm{hr}$. after inoculation. One filament shows 'elbow' swelling. $70 \mathrm{kV} . \times 22,000$.

\section{Plate 3}

Fig. 11. A group of filaments escaping from an infected fibroblast, $64 \mathrm{hr}$. after inoculation. $75 \mathrm{kV}$., $70 \mu$. objective aperture. $\times 10,000$.

Fig. 12. A peculiar spherical structure occasionally seen in infected fibroblasts. The filaments in the picture show segmentation. $\times 22,000$.

Fig. 13. Cytoplasmic debris, filaments and a few elementary bodies. Disintegrating fibroblast, $72 \mathrm{hr}$. after inoculation. $\times 10,000$.

Fig. 14. Cytoplasm of epithelial cell, $24 \mathrm{hr}$. after inoculation with Nederland 1 strain of influenza A-prime virus. $\times 10,000$. (Electron micrograph by Dr I. M. Dawson.) 
Journal of General Microbiology, Vol. 5, No. 2
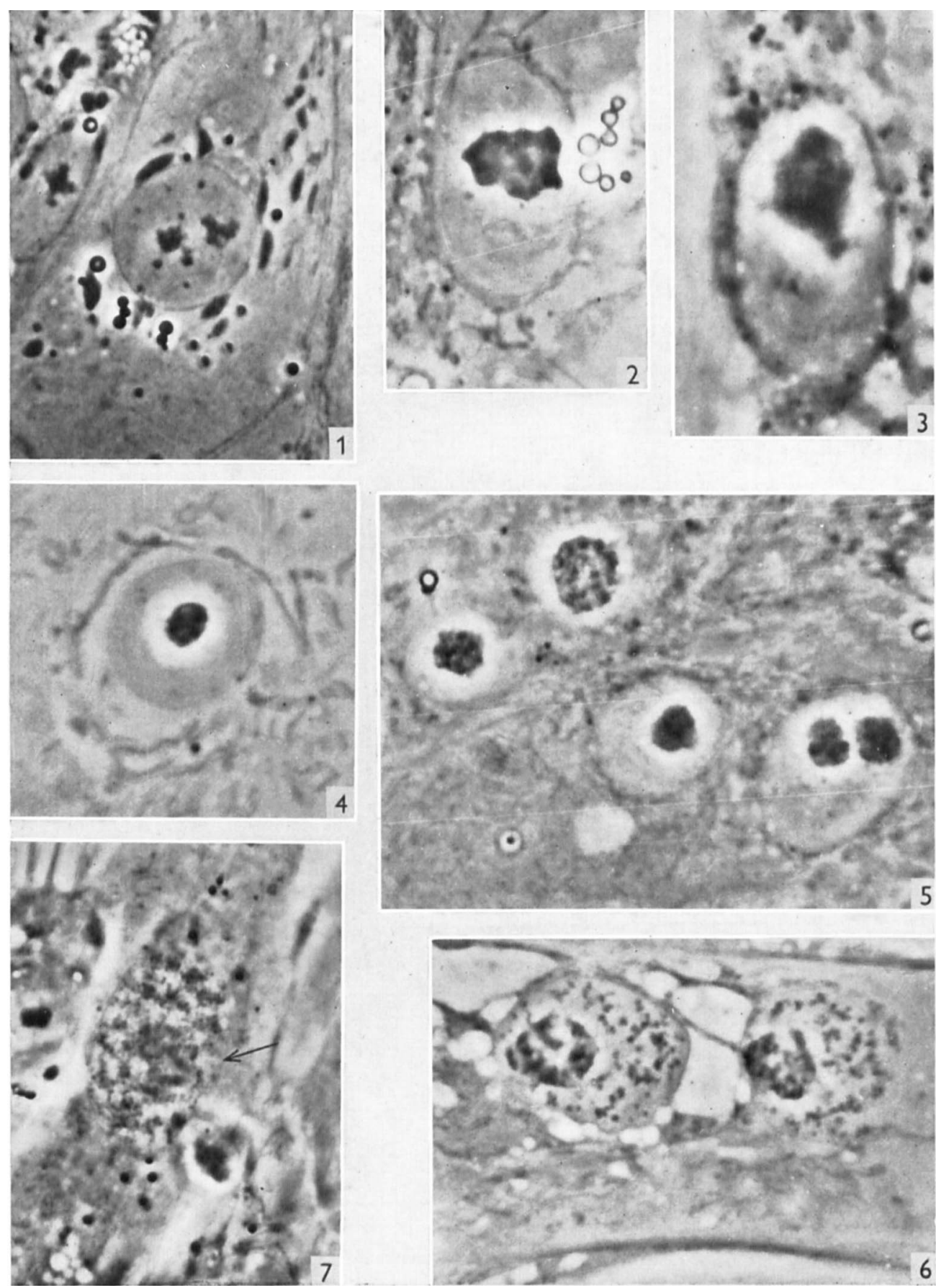

T. H. Flewett \& C. E. Challis-Intracellular growth of fowl-Plague virus. Plate 1 
Journal of General Microbiology, Vol. 5, No. 2
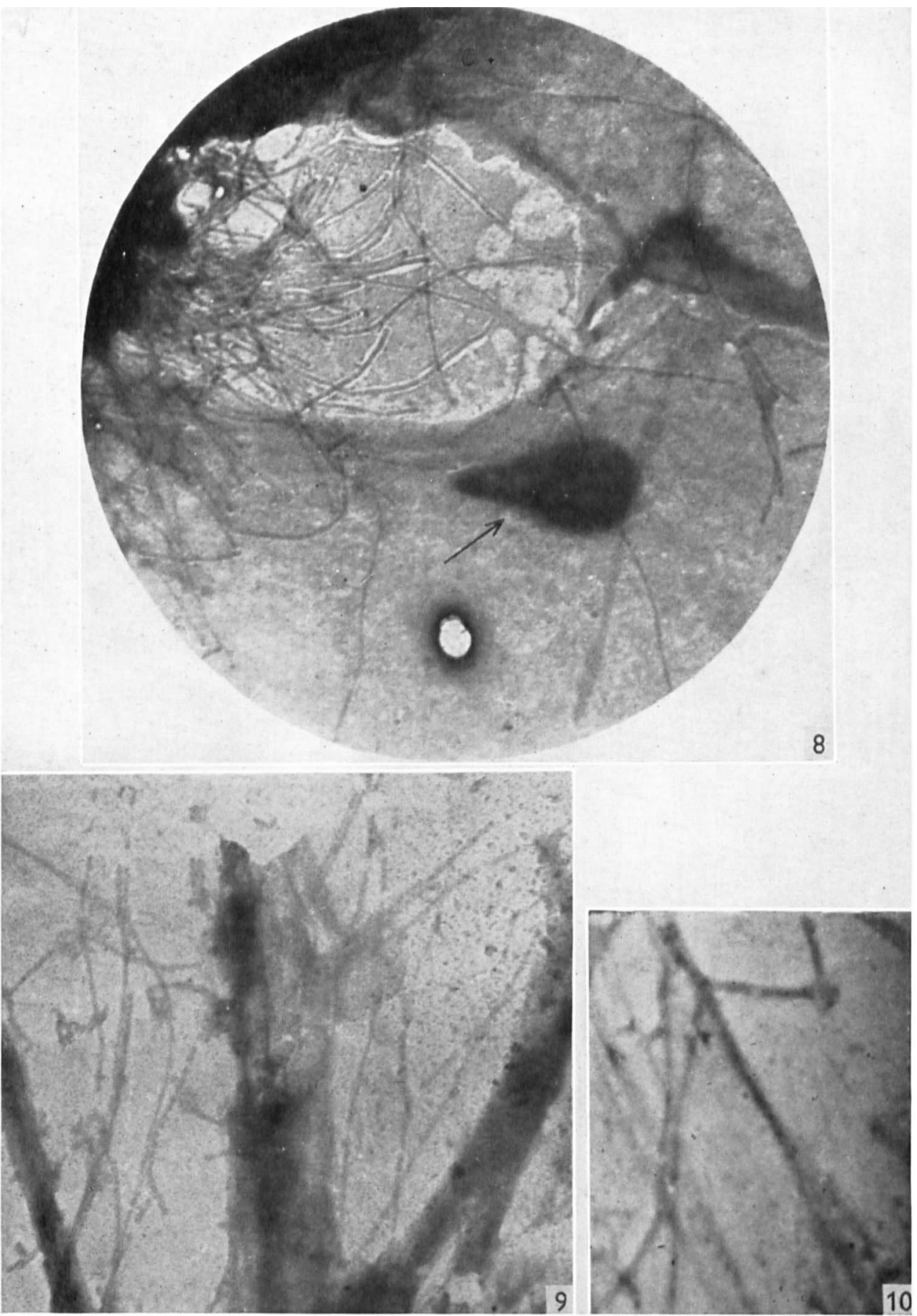

T. H. Flewett \& C. E. Challis-Intracellular growth of fowl-plague virus. Plate 2 
Journal of General Microbiology, Vol. 5, No. 2
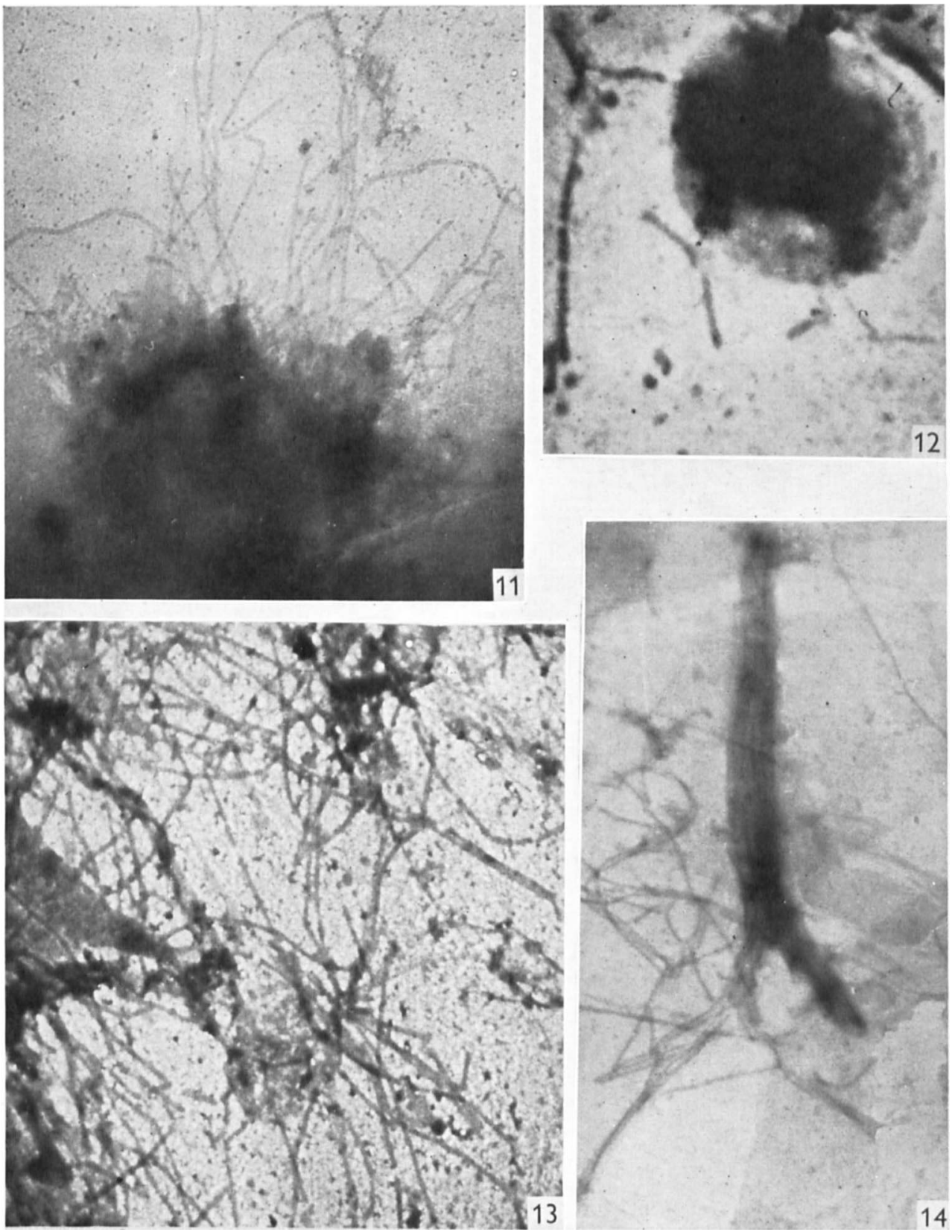

T. H. Flewett \& C. E. Challice-Intracellular grow'th of fowl-plague virus. Plate 3 